\title{
Biocompatibility assessment of different root-end filling materials implanted subcutaneously in rats: An in vivo study
}

\author{
Dina Rady ${ }^{1,2, A-F}$, Mai Hisham Abdel Rahman ${ }^{3, A, D, E}$, Sara El-Mallah ${ }^{4, A, B, F}$, Mennatullah Mohammed Khalil ${ }^{5, A, E, F}$ \\ ${ }^{1}$ Department of Oral Biology, Faculty of Dentistry, Cairo University, Egypt \\ ${ }^{2}$ Stem Cells and Tissue Engineering Research Group, Faculty of Dentistry, Cairo University, Egypt \\ ${ }^{3}$ Department of Biomaterials, Faculty of Dentistry, Modern Science and Arts University, Cairo, Egypt \\ ${ }^{4}$ Department of Endodontics, Faculty of Dentistry, Fayoum University, Egypt \\ ${ }^{5}$ Department of Biomaterials, Faculty of Dentistry, Fayoum University, Egypt \\ A - research concept and design; $\mathrm{B}$ - collection and/or assembly of data; $\mathrm{C}$ - data analysis and interpretation; \\ $D$ - writing the article; $E$ - critical revision of the article; $F$ - final approval of the article
}

Address for correspondence

Dina Rady

E-mail: dina.radi@dentistry.cu.edu.eg

Funding sources

None declared

Conflict of interest

None declared

Acknowledgements

The authors would like to thank Dr. Israa Ahmed Gamal for great help in conducting the statistical analysis.

Received on August 28, 2020

Reviewed on January 1, 2021

Accepted on January 7, 2021

Published online on December 31, 2021

Cite as

Rady D, Abdel Rahman MH, El-Mallah S, Khalil MM. Biocompatibility assessment of different root-end filling materials implanted subcutaneously in rats: An in vivo study. Dent Med Probl. 2021;58(4):525-532. doi:10.17219/dmp/132240

DOI

$10.17219 / \mathrm{dmp} / 132240$

Copyright

○) 2021 by Wroclaw Medical University

This is an article distributed under the terms of the

Creative Commons Attribution 3.0 Unported License (CC BY 3.0)

(https://creativecommons.org/licenses/by/3.0/).

\section{Abstract}

Background. Root-end filling materials are used in surgical endodontic treatment to seal the teeth periapically. Ideally, these materials should prevent bacterial leakage by tightly sealing the canal, be biocompatible with the periapical tissues, and preferably stimulate the regeneration of dentin, contributing to the success of treatment.

Objectives. The purpose of this study was to evaluate and compare the biocompatibility of the GuttaFlow $^{\circledR}$ Bioseal cement in relation to MTA Angelus ${ }^{\circledR}$ and Zical ${ }^{\circledR}$ after implantation into the subcutaneous tissue of rats.

Material and methods. Eighteen male albino rats were used in the study. Four polyethylene tubes were implanted in the backs of the rats (3 tubes containing the test materials and 1 empty tube as a control). Nine animals were sacrificed at each interval of 7 and 30 days, and the implants were removed with the surrounding tissue. The samples were evaluated for stromal inflammatory response, fibrous tissue formation, vascular reactivity, and the presence of multinucleated giant cells (MNGCS).

Results. On day 7, the capsules in all subgroups revealed moderate to severe inflammatory reactions with the presence of inflammatory cells, multiple irregular collagen fibers, dilated blood vessels, and MNGCS. However, on day 30 , tissue organization was more evident with a reduction in the inflammatory response. In this time interval, the tissue in contact with GuttaFlow Bioseal showed progressive healing with a wellformed fibrous capsule. Conversely, the tissue close to MTA Angelus revealed a fibrous capsule of limited organization with mild pericapsular fibrosis and vascular congestion. Zical showed a mild to moderate persistent inflammatory reaction and vascular reactivity.

Conclusions. The 3 cements demonstrated more severe irritation at the beginning that became milder with time. GuttaFlow Bioseal yielded better tissue organization than MTA Angelus and Zical. Thus, these findings strongly suggest that GuttaFlow Bioseal is a promising material for root-end filling.

Keywords: subcutaneous tissue, bioseal, GuttaFlow, MTA Angelus, Zical 


\section{Introduction}

The majority of unsuccessful endodontic treatment is the result of the irritants leaking from the infected root canal into the periapical tissues. When non-surgical treatment is unsuccessful or contraindicated, the only solution to save the tooth is via a surgical intervention. ${ }^{1,2}$ Surgical endodontic treatment involves root-end preparation followed by the placement of an appropriate root-end filling material. An ideal root-end filling material should provide a tight hermetic seal to prevent microleakage, which could further contaminate the periapical tissues. ${ }^{3}$ These materials are in direct contact with the tissues, and therefore, must be biocompatible to avoid further irritation and possible treatment failure. ${ }^{4}$ Preferably, the root-end filling material should have the ability to stimulate the periodontium to regenerate while also being bacteriostatic or bactericidal to help accelerate the healing process and reduce the failure rate. ${ }^{3,5}$ The material should also be non-toxic, non-carcinogenic and dimensionally stable. ${ }^{2,3}$

The polydimethylsiloxane cements which contain very finely ground gutta-percha are used as cold filling systems for root canals; this formulation is commercially available as GuttaFlow ${ }^{\circledR}$. Such cements have been introduced to overcome the disadvantages of warm obturation techniques. ${ }^{6}$ GuttaFlow is bioactive due to the addition of silica, calcium oxide and phosphorous oxide particles; it has been introduced onto the market as GuttaFlow Bioseal. The substances added to the cement play a role in the stimulation of tissue regeneration and healing. ${ }^{7}$ GuttaFlow Bioseal is characterized by low solubility, high bond strength, minimal calcium release, and alkalinizing activity. ${ }^{8-10}$

Mineral trioxide aggregate (MTA) is the best known bioactive cement in the endodontic field. This cement is widely used in different endodontic treatment, including root-end surgeries, root perforation repair, internal resorption, pulp capping, apexification, and obturation. It is mainly composed of tricalcium silicate, dicalcium silicate, tricalcium aluminate, tetracalcium aluminoferrite, dehydrated calcium sulfate, and bismuth oxide. Its bioactivity is due to the rise in $\mathrm{pH}$ to 12.5 that occurs after $3 \mathrm{~h}$ of mixing, which subsequently stimulates interleukin production and calcium ion release. ${ }^{11}$ Mineral trioxide aggregate has been found to stimulate hard tissue deposition when applied as a retro-filling material in endodontically treated dogs' teeth. ${ }^{12}$ There are several drawbacks to the use of MTA, including a long setting time, difficult handling, low strength, and a high cost. ${ }^{13}$

Traditionally, zinc oxide-eugenol $(\mathrm{ZnO} / \mathrm{E})$ cements have been among the most commonly used and recommended cements with a long history of successful use. Despite their positive characteristics, they have several shortcomings that have favored their replacement, including a long setting time, excessive solubility and the lack of adhesion. ${ }^{10,14,15}$

Accordingly, this study aimed to evaluate and compare the biocompatibility promoted by the polydimethylsiloxane-gutta-percha calcium silicate-containing cement (GuttaFlow Bioseal) in relation to MTA (MTA Angelus ${ }^{\circledR}$ ) and $\mathrm{ZnO} / \mathrm{E}\left(\mathrm{Zical}^{\mathbb{R}}\right)$ after implantation into the subcutaneous connective tissue of rats.

\section{Material and methods}

The cements used in the study were GuttaFlow Bioseal (Coltène/Whaledent, Altstätten, Switzerland), MTA Angelus (Angelus, Londrina, Brazil) and Zical (Prevest DenPro Limited, Jammu, India). The composition of the materials is described in Table 1 .

\section{Animal study design}

This experiment was conducted in the Animal House of the Faculty of Medicine, Cairo University, Egypt, according to the guidance and approval of the Institutional Animal Care \& Use Committee of Cairo University (CU-IACUC) (approval No. CU III F 7718).

Eighteen adult male albino rats with an average weight of 150-200 g were provided by the Animal House of the Faculty of Medicine, Cairo University, Egypt. The animals

Table 1. Endodontic cements used in the study

\begin{tabular}{|c|c|c|c|c|}
\hline Commercial name & Manufacturer & Presentation & Composition & Lot No. \\
\hline GuttaFlow Bioseal & $\begin{array}{l}\text { Coltène/Whaledent, } \\
\text { Altstätten, Switzerland }\end{array}$ & dual-barrel syringe & $\begin{array}{l}\text { gutta-percha powder particles, polydimethylsiloxane, } \\
\text { platinum catalyst, zirconium dioxide, calcium salicylate, nanosilver } \\
\text { particles, paraffin, coloring, } \\
\text { and bioactive glass ceramic }\end{array}$ & H84160 \\
\hline MTA Angelus & $\begin{array}{c}\text { Angelus, } \\
\text { Londrina, Brazil }\end{array}$ & $\begin{array}{l}\text { powder } \\
\text { and liquid }\end{array}$ & $\begin{array}{c}\text { powder: } \\
\text { tricalcium silicate, dicalcium silicate, tricalcium aluminate, tetracalcium } \\
\text { aluminoferrite, dehydrated calcium sulfate, and bismuth oxide; } \\
\text { liquid:distilled water }\end{array}$ & 101648 \\
\hline Zical & $\begin{array}{l}\text { Prevest DenPro Limited, } \\
\text { Jammu, India }\end{array}$ & $\begin{array}{l}\text { powder } \\
\text { and liquid }\end{array}$ & $\begin{array}{c}\text { powder: } \\
\text { zinc oxide, } \\
\text { bismuth subcarbonate, barium sulfate, sodium borate, iodoform, } \\
\text { and hydrogenated resin; } \\
\text { liquid: eugenol }\end{array}$ & 1521802 \\
\hline
\end{tabular}


were kept in an aerated chamber with 12-h dark/light intervals, divided according to the study period. The cages were cleaned on a daily basis, and the rats were allowed unlimited access to food and water. The animals were randomly divided into 2 groups ( $n=9$ in each group), according to the sacrifice dates (7 days and 30 days). These groups were further subdivided into 4 subgroups according to the material used:

- subgroup 1 - polyethylene tubes filled with GuttaFlow Bioseal $(n=9)$;

- subgroup 2 - polyethylene tubes filled with MTA Angelus $(n=9)$;

- subgroup 3 - polyethylene tubes filled with Zical $(n=9)$;

- subgroup 4 - empty polyethylene tubes (control) $(n=9)$.

The materials were mixed under aseptic conditions, according to the manufacturers' instructions. Sterile polyethylene tubes were filled with GuttaFlow Bioseal or MTA Angelus and set within 15 min after being prepared, Zical, or left empty. They were immediately implanted into the dorsal subcutaneous tissue of the animals.

The back of each animal was shaved in 4 areas (upper right, upper left, lower right, and lower left) and disinfected with $10 \%$ betadine antiseptic solution (Mundipharma Egypt co., Cairo, Egypt). The animals were anesthetized with an intraperitoneal injection of ketamine ( $80 \mathrm{mg} / \mathrm{kg}$ of body weight (b.w.)) combined with xylazine hydrochloride $(8 \mathrm{mg} / \mathrm{kg}$ b.w.). Incisions of $2 \mathrm{~cm}$ in length were made in the head-tail orientation, creating 2 pockets on each side of the back of each rat (Fig. 1). After the polyethylene tubes were implanted, the skin was closed using 4/0 silk sutures (International Sutures Manufacturing Co., Cairo, Egypt). Postoperatively, each animal received $10 \mathrm{mg} / \mathrm{kg}$ b.w. Flumox ${ }^{\circledR}$ (EIPICO, Tenth of Ramadan City, Egypt) intramuscularly to avoid secondary bacterial infection, $10 \mathrm{mg} / \mathrm{kg}$ b.w. Cataflam ${ }^{\circledR}$ (Novartis, Cairo, Egypt) to avoid any possibility of postoperative pain as well as topical antibiotic spray Bivatracin (ECAP, Cairo, Egypt) to avoid local infection. On days 7 and 30 after implantation, the animals were euthanized by intracardiac overdose of sodium thiopental ( $80 \mathrm{mg} / \mathrm{kg}$ b.w.). ${ }^{16}$

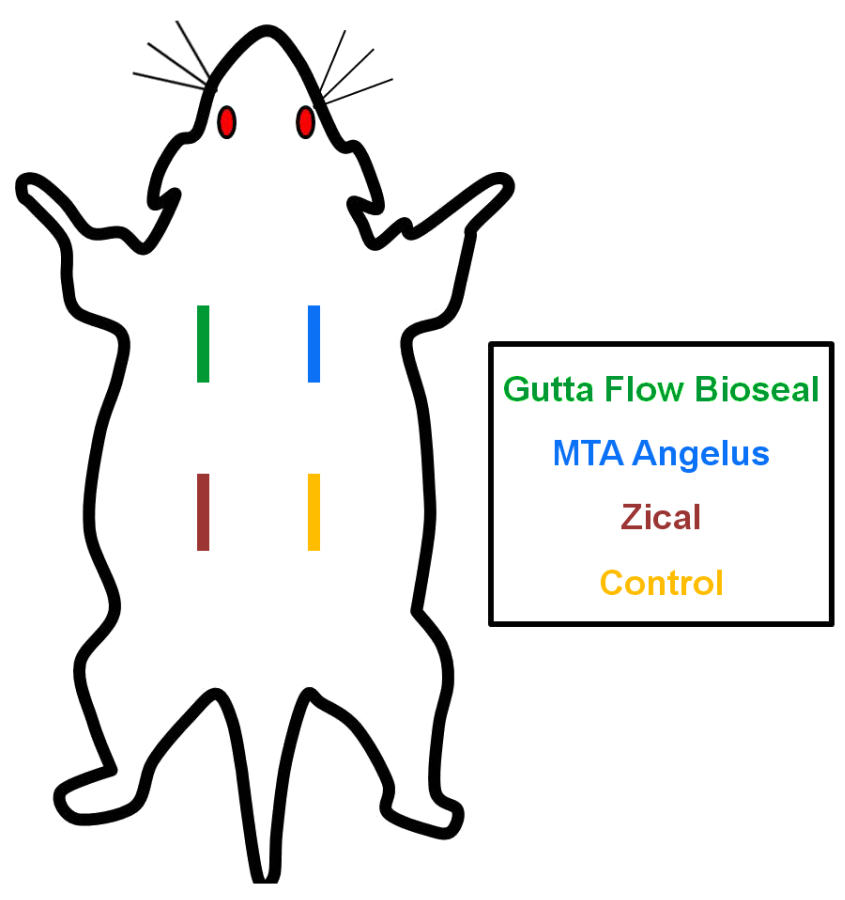

Fig. 1. Diagrammatic presentation of the 4 incision sites and materials implanted into the dorsum of the rats

\section{Histopathologic evaluation}

Samples of skin and subcutaneous tissues containing the implants were excised with a safety margin of $1 \mathrm{~cm}$. They were placed in $10 \%$ formalin at $\mathrm{pH} 7.2$, buffered with $0.1 \mathrm{M}$ sodium phosphate at room temperature for $24 \mathrm{~h}$ to allow fixation. Subsequently, the polyethylene tubes were carefully removed from the samples. Next, the tissues were dehydrated in graded ethanol, treated with xylene and embedded in paraffin. Longitudinal sections, 4-micrometer thick, were stained with hematoxylin and eosin (H\&E) for morphological and morphometrical analyses.

The tissue reaction at the end of the tubes was scored according to a previous study, including stromal inflammatory response (mononuclear cells), fibrous tissue formation, vascular reactivity, and the presence of multinucleated giant cells (MNGCs) (Table 2). ${ }^{17}$ The histopathological evaluation was performed using light mi-

Table 2. Criteria for scoring the severity of reaction

\begin{tabular}{|c|c|c|c|c|}
\hline Criterion & 0 & 1 & 2 & 3 \\
\hline $\begin{array}{l}\text { Stromal } \\
\text { inflammatory } \\
\text { response }\end{array}$ & $\begin{array}{c}\text { - no reaction } \\
\text { - few inflammatory cells }\end{array}$ & $\begin{array}{l}\text { - mild reaction } \\
\text { - less than } 25 \text { inflammatory cells }\end{array}$ & $\begin{array}{c}\text { - moderate reaction } \\
\text { - 25-125 inflammatory cells }\end{array}$ & $\begin{array}{c}\text { - severe reaction } \\
\text { - more than } 125 \text { inflammatory } \\
\text { cells }\end{array}$ \\
\hline $\begin{array}{l}\text { Fibrous tissue } \\
\text { formation }\end{array}$ & $\begin{array}{l}\text { - no reaction } \\
\text { - normal collagen fiber } \\
\text { morphology }\end{array}$ & $\begin{array}{l}\text { - mild reaction } \\
\text { - mild collagen fiber irregularity }\end{array}$ & $\begin{array}{c}\text { - moderate reaction } \\
\text { - moderate collagen fiber } \\
\text { irregularity }\end{array}$ & $\begin{array}{l}\text { - severe reaction } \\
\text { - severe collagen fiber } \\
\text { irregularity }\end{array}$ \\
\hline $\begin{array}{l}\text { Vascular } \\
\text { reactivity }\end{array}$ & $\begin{array}{l}\text { - no reaction } \\
\text { - no significant vascular } \\
\text { proliferation }\end{array}$ & $\begin{array}{l}\text { - mild reaction } \\
\text { - number of vascular structures } \\
\text { in } 1 \text { high-power field }(\times 40)<25\end{array}$ & $\begin{array}{l}\text { - moderate reaction } \\
\text { - number of vascular structures } \\
\text { in } 1 \text { high-power field }(\times 40) 25-50\end{array}$ & $\begin{array}{l}\text { - severe reaction } \\
\text { - number of vascular structures } \\
\text { in } 1 \text { high-power field }(\times 40)>50\end{array}$ \\
\hline MNGCs & absent & present & present & present \\
\hline
\end{tabular}

MNGCs - multinucleated giant cells. 
croscopy (Leica Microsystems, Heerbrugg, Switzerland) under $\times 400$ magnification, while the analyses of the connective tissue capsule thickness, ${ }^{18}$ the number of cell layers in the capsule ${ }^{19}$ and the collagen fiber diameter were performed on images acquired with $\times 100$ magnification. Five fields were measured from each sample and the mean values were calculated.

The Fiji ImageJ software (https://imagej.net/software/ fiji/) ${ }^{20}$ was utilized. The data was obtained using the Leica Qwin 500 Image Analysis Software (Leica Microsystems). The image analyzer consisted of a colored video camera, a colored monitor, and the hard drive of an IBM personal computer (IBM Corp., Armonk, USA) connected to the microscope controlled by the Leica Qwin 500 software.

\section{Statistical analysis}

The statistical analysis of the tissue response was performed at day 7 and day 30. Differences in the grades assigned to particular subgroups and between the 2 experimental periods were presented as frequency, and were evaluated using the Mann-Whitney $U$ test and Kruskall-Wallis non-parametric test followed by a post hoc test. The thickness of the connective tissue capsule, the number of cell layers in the capsule and the collagen fiber diameter were analyzed using the two-way analysis of variance (ANOVA) followed by a post hoc test. The level of significance was set at 0.05 .

\section{Results}

In all 4 subgroups in both time periods, mild to severe inflammation, vascular reactivity, fibrous tissue formation, and the presence of MNGCs were observed (Table 3, 4; Fig. 2, 3).

\section{Microscopic analysis of the tissue-material interface}

On day 7, all subgroups showed moderate to severe stromal inflammatory response on the capsule at the tissuematerial interface. The experimental subgroups displayed inflammatory cell infiltration, mainly lymphocytes and macrophages, with increased levels of new blood vessel formation around them. The connective tissue was poorly organized with a few MNGCs (Fig. 2A-D). The remnants of the implanted material were observed in the MTA Angelus subgroup (Fig. 2B). As compared to the experimental subgroups, the control subgroup showed more organized connective tissue with moderate macrophage and lymphocyte infiltration as well as a small fibrin clot (Fig. 2D).

Table 3. Comparison of the $p$-values of the subgroups at the 2 time periods for the criteria assessed

\begin{tabular}{|c|c|c|c|c|c|c|c|c|c|c|}
\hline Criterion & Day & $\begin{array}{l}\text { GuttaFlow } \\
\text { Bioseal }\end{array}$ & Day & $\begin{array}{c}\text { MTA } \\
\text { Angelus }\end{array}$ & Day & Zical & Day & Control & Day & $\begin{array}{c}p \text {-value } \\
\text { (between subgroups) }\end{array}$ \\
\hline \multirow{2}{*}{$\begin{array}{l}\text { Stromal inflammatory } \\
\text { response }\end{array}$} & $7^{b}$ & \multirow{2}{*}{$0.028^{*}$} & $7^{b}$ & \multirow{2}{*}{$0.011^{*}$} & $7^{\mathrm{a}}$ & \multirow{2}{*}{$0.003^{*}$} & $7^{b}$ & \multirow{2}{*}{$0.011^{*}$} & 7 & $0.006^{*}$ \\
\hline & $30^{\mathrm{b}}$ & & $30^{b}$ & & $30^{\mathrm{a}}$ & & $30^{\mathrm{b}}$ & & 30 & $0.004^{*}$ \\
\hline \multirow[b]{2}{*}{ Fibrous tissue formation } & 7 & \multirow[b]{2}{*}{0.073} & 7 & \multirow[b]{2}{*}{0.150} & 7 & \multirow[b]{2}{*}{$0.033^{*}$} & 7 & \multirow[b]{2}{*}{0.298} & 7 & 0.065 \\
\hline & 30 & & 30 & & 30 & & 30 & & 30 & 0.442 \\
\hline \multirow{2}{*}{ Vascular reactivity } & $7^{\mathrm{a}}$ & \multirow{2}{*}{$0.001^{*}$} & $7^{\mathrm{a}}$ & \multirow{2}{*}{$0.011^{*}$} & $7^{a}$ & \multirow{2}{*}{$0.008^{*}$} & $7^{b}$ & \multirow{2}{*}{0.140} & 7 & $0.003^{*}$ \\
\hline & $30^{b}$ & & $30^{a, b}$ & & $30^{\mathrm{a}}$ & & $30^{\mathrm{b}}$ & & 30 & $0.018^{*}$ \\
\hline \multirow{2}{*}{ MNGCs } & $7^{\mathrm{a}}$ & \multirow{2}{*}{$0.028^{*}$} & $7^{b}$ & \multirow{2}{*}{1.000} & $7^{a}$ & \multirow{2}{*}{$0.028^{*}$} & $7^{b}$ & \multirow{2}{*}{1.000} & 7 & $0.019^{*}$ \\
\hline & 30 & & 30 & & 30 & & 30 & & 30 & 1.000 \\
\hline
\end{tabular}

* - statistically significant. Within the same row (whenever the difference between the subgroups is statistically significant), the same superscript letter means no statistically significant difference.

Table 4. Scoring of histopathologic events observed in each subgroup at the 2 time periods

\begin{tabular}{|c|c|c|c|c|c|c|c|c|c|c|c|c|c|c|c|c|c|c|}
\hline \multirow{2}{*}{ Criterion } & \multirow{2}{*}{ Day } & \multirow{2}{*}{$n$} & \multicolumn{4}{|c|}{ GuttaFlow Bioseal } & \multicolumn{4}{|c|}{ MTA Angelus } & \multicolumn{4}{|c|}{ Zical } & \multicolumn{4}{|c|}{ Control } \\
\hline & & & G0 & G1 & $\mathrm{G} 2$ & G3 & G0 & G1 & G2 & G3 & Go & G1 & G2 & G3 & G0 & G1 & G2 & G3 \\
\hline \multirow{2}{*}{$\begin{array}{l}\text { Stromal } \\
\text { inflammatory } \\
\text { response }\end{array}$} & 7 & 9 & 0 & 5 & 4 & 0 & 0 & 4 & 5 & 0 & 0 & 0 & 5 & 4 & 0 & 4 & 5 & 0 \\
\hline & 30 & 9 & 0 & 9 & 0 & 0 & 0 & 9 & 0 & 0 & 0 & 5 & 4 & 0 & 0 & 9 & 0 & 0 \\
\hline \multirow{2}{*}{$\begin{array}{l}\text { Fibrous tissue } \\
\text { formation }\end{array}$} & 7 & 9 & 0 & 3 & 6 & 0 & 0 & 3 & 5 & 1 & 0 & 1 & 6 & 2 & 0 & 6 & 3 & 0 \\
\hline & 30 & 9 & 0 & 7 & 2 & 0 & 0 & 6 & 3 & 0 & 0 & 5 & 4 & 0 & 0 & 8 & 1 & 0 \\
\hline \multirow{2}{*}{$\begin{array}{l}\text { Vascular } \\
\text { reactivity }\end{array}$} & 7 & 9 & 0 & 0 & 6 & 3 & 0 & 0 & 6 & 3 & 0 & 0 & 4 & 5 & 0 & 5 & 4 & 0 \\
\hline & 30 & 9 & 0 & 7 & 2 & 0 & 0 & 4 & 5 & 0 & 0 & 2 & 7 & 0 & 0 & 8 & 1 & 0 \\
\hline \multirow{2}{*}{ MNGCs } & 7 & 9 & 5 & 4 & 0 & 0 & 9 & 0 & 0 & 0 & 5 & 4 & 0 & 0 & 9 & 0 & 0 & 0 \\
\hline & 30 & 9 & 9 & 0 & 0 & 0 & 9 & 0 & 0 & 0 & 9 & 0 & 0 & 0 & 9 & 0 & 0 & 0 \\
\hline
\end{tabular}

G-grade. 


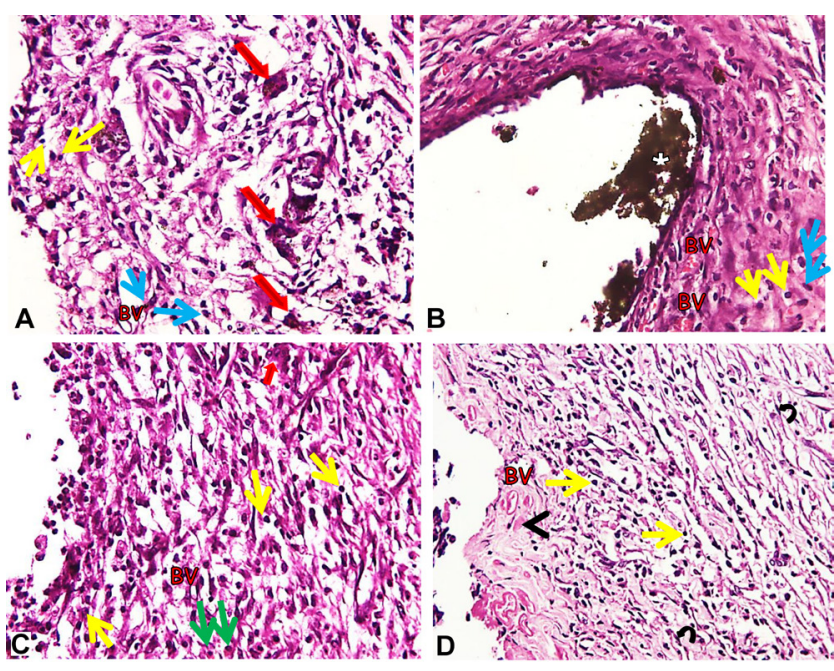

Fig. 2. Photomicrographs of hematoxylin and eosin (H\&E) staining sections showing a portion of the capsule at the tissue-material interface on day 7

A - GuttaFlow Bioseal; B - MTA Angelus; C - Zical; D - control; $\times 400$ magnification.

The capsules show a moderate to severe inflammatory reaction. The capsules exhibit several inflammatory cells, mainly lymphocytes (yellow arrows), plasma cells (blue arrows) and macrophages (green arrows). Multinucleated giant cells (MNGCs) (red arrows) and blood vessels (BV) are observed. Fibroblastic activity (curved arrow) and minimal fibrinoid-like deposition (black-arrow head) are observed in 2D.

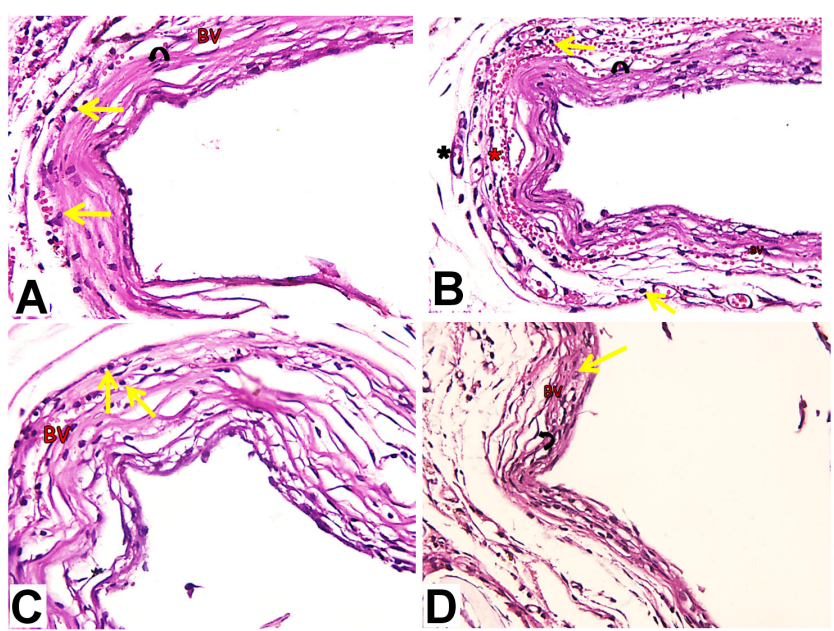

Fig. 3. Photomicrographs of hematoxylin and eosin (H\&E) staining sections showing a portion of the capsule at the tissue-material interface on day 30

A - GuttaFlow Bioseal; B - MTA Angelus; C - Zical; D - control;

$\times 400$ magnification.

The fibrous capsule shows mild inflammatory cell infiltration in 3A, 3B and 3D. Mild pericapsular fibrosis (red asterisks) and congested capillaries (black asterisks) are observed in 3B. Mild to moderate inflammation is observed in 3C. The remodeling of the fibrous capsule and collagen fibers with marked fibroblastic activity (curved arrow) is observed in 3D

On day 30, all subgroups showed a mild to moderate inflammatory tissue response on the capsule at the tissue-material interface. The GuttaFlow Bioseal subgroup showed progressive healing with a well-formed fibrous capsule; it also exhibited multiple parallel collagen fibers with a marked decrease in inflammatory cell infiltration (Fig. 3A). The MTA Angelus subgroup exhibited a fibrous capsule of limited organization with mild peri-capsular fibrosis, including some congested capillaries (Fig. 3B). The Zical subgroup showed significantly more inflammatory cells, vascular reactivity and collagen fiber irregularity as compared to other subgroups (Fig. 3C). The control subgroup displayed more organized tissue with predominant connective tissue fibers, fibroblasts and inflammatory reactions (Fig. 3D). Fibroblasts were observed among the inflammatory cells and blood vessels in all subgroups (Fig. 3A-D). Multinucleated giant cells were absent in all subgroups.

Considering the severity of the inflammatory reaction displayed by the subgroups, there were statistically significant differences in stromal inflammatory response between the subgroups on day 7 and day $30(p=0.006$ and $p=0.004$, respectively), with a larger number of inflammatory cells in the Zical subgroup on both observation days. There were no statistically significant differences in fibrous tissue formation between the subgroups on day 7 and day 30 ( $p=0.065$ and $p=0.442$, respectively). There were statistically significant differences in vascular changes between the subgroups on day 7 and day $30(p=0.003$ and $p=0.018$, respectively), with the greatest amount of vascular changes recorded in the Zical subgroup. There were statistically significant differences in MNGCs between the subgroups on day 7 ( $p=0.019)$, but not on day $30(p=1.000)$ (Table 3$)$.

Comparing the 2 observation times, stromal inflammatory response decreased statistically significantly between the time periods for the GuttaFlow Bioseal, MTA Angelus, Zical, and control subgroups $(p=0.028, p=0.011$, $p=0.003$, and $p=0.011$, respectively). Although it was not statistically significant, fibrous tissue formation decreased over time for the GuttaFlow Bioseal, MTA Angelus and control subgroups $(p=0.073, p=0.150, p=0.298$, respectively). Conversely, a statistically significant decrease was recorded on day 30 in the Zical subgroup $(p=0.033)$. There was a statistically significant decrease in vascular reactivity between the time periods for the GuttaFlow Bioseal, MTA Angelus and Zical subgroups $(p=0.001, p=0.011$ and $p=0.008$, respectively), while the control subgroup showed no significant difference between the 2 observation times $(p=0.140)$. There was a statistically significant difference between the 2 observation times for MNGCs in the GuttaFlow Bioseal and Zical subgroups $(p=0.028$ and $p=0.028$, respectively), but this difference was not statistically significant for the MTA Angelus and control subgroups ( $p=1.000$ and $p=1.000$, respectively) (Table 3 ).

The connective tissue capsule thickness and the number of cell layers in the capsule decreased, while the collagen fiber diameter increased in all subgroups with regard to both time periods. An increase in the collagen fiber diameter was not statistically significant $(p=0.101)$, but decreases in the connective tissue capsule thickness and the number of cell layers in the capsule were statistically significant $(p<0.05)$ (Table 5).

On day 7, the capsules exhibited a well-defined structure of variable thickness; the highest mean capsule thickness was detected in the Zical subgroup, while the lowest value was detected in the control subgroup on day 30 (Table 5). 
Table 5. Comparison of the subgroups at the 2 time periods in terms of particular parameters

\begin{tabular}{|c|c|c|c|c|c|c|}
\hline Parameter & Day & Control & Zical & MTA Angelus & GuttaFlow Bioseal & $p$-value \\
\hline \multirow{2}{*}{$\begin{array}{l}\text { Connective tissue capsule thickness } \\
\text { [um] }\end{array}$} & 7 & $103.15 \pm 10.72 C, D$ & $323.53 \pm 70.38 \mathrm{~A}$ & $236.28 \pm 22.60 B$ & $119.64 \pm 20.20 C$ & \multirow{2}{*}{$0.000^{*}$} \\
\hline & 30 & $48.18 \pm 12.74 \mathrm{E}$ & $72.30 \pm 15.71 \mathrm{D}, \mathrm{E}$ & $69.89 \pm 6.58 \mathrm{D}, \mathrm{E}$ & $59.79 \pm 10.71 E$ & \\
\hline \multirow{2}{*}{$\begin{array}{l}\text { Number of cell layers } \\
\text { (n) }\end{array}$} & 7 & $4.67 \pm 1.32 C, D$ & $9.17 \pm 1.00 \mathrm{~A}$ & $9.06 \pm 0.53 \mathrm{~A}$ & $8.33 \pm 0.71 \mathrm{~A}$ & \multirow{2}{*}{$0.000^{*}$} \\
\hline & 30 & $4.39 \pm 0.70 D$ & $6.11 \pm 1.05 B$ & $5.78 \pm 0.71 B, C$ & $4.72 \pm 0.83 C, D$ & \\
\hline \multirow{2}{*}{$\begin{array}{l}\text { Collagen fiber diameter } \\
\text { [um] }\end{array}$} & 7 & $1.96 \pm 0.92$ & $4.61 \pm 0.69$ & $4.66 \pm 1.03$ & $2.62 \pm 1.32$ & \multirow{2}{*}{0.101} \\
\hline & 30 & $2.45 \pm 1.25$ & $6.64 \pm 0.82$ & $5.12 \pm 1.59$ & $4.30 \pm 1.40$ & \\
\hline
\end{tabular}

Data presented as mean \pm standard deviation $(M \pm S D) .{ }^{*}$ - statistically significant. The same superscript letter means no statistically significant difference.

The pairwise comparison revealed statistically significant differences between the Zical subgroup on day 7 and the following subgroups: control on day $7(p<0.05)$; control on day $30(p<0.05)$; GuttaFlow Bioseal on day $7(p<0.05)$; GuttaFlow Bioseal on day $30(p<0.05)$; MTA Angelus on day $7(p<0.05)$; and MTA Angelus on day $30(p<0.05)$.

Furthermore, the pairwise comparison showed statistically significant differences between the Zical subgroup on day 30 and the following subgroups: Zical on day 7 $(p<0.05)$; GuttaFlow Bioseal on day $7(p=0.018)$; and MTA Angelus on day $7(p<0.05)$.

A significant relationship was also detected between the MTA Angelus subgroup on day 7 and the control subgroup on day $7(p<0.05)$, the control subgroup on day $30(p<0.05)$, the GuttaFlow Bioseal subgroup on day 7 $(p<0.05)$, and the GuttaFlow Bioseal subgroup on day 30 $(p<0.05)$. Moreover, there was a significant relationship between the MTA Angelus subgroup on day 30 and the MTA Angelus subgroup on day $7(p<0.05)$ and the GuttaFlow Bioseal subgroup on day $7(p=0.010)$.

Additionally, a significant relationship was detected between the GuttaFlow Bioseal subgroup on day 7 and the control subgroup on day $30(p<0.05)$. There was also a significant relationship between the GuttaFlow Bioseal subgroup on day 30 and the GuttaFlow Bioseal subgroup on day $7(p=0.001)$ and the control subgroup on day 7 $(p=0.040)$.

Moreover, there was a significant relationship between the control subgroup on day 30 and the control subgroup on day $7(p=0.003)$.

Regarding the number of cell layers in the capsule, the highest mean number of cell layers was detected in the $\mathrm{Zi}$ cal subgroup on day 7, while the lowest number of cell layers was detected in the control subgroup on day 30; this difference was statistically significant $(p<0.05)$.

The pairwise comparison revealed a statistically significant relationship between the Zical subgroup on day 7 and the control subgroup on day $7(p<0.05)$, the control subgroup on day $30(p<0.05)$, the MTA Angelus subgroup on day $30(p<0.05)$, and the GuttaFlow Bioseal subgroup on day $30(p<0.05)$. There was also a statistically significant relationship between the Zical subgroup on day 30 and the Zical subgroup on day $7(p<0.05)$, the control subgroup on day $7(p=0.021)$, the control subgroup on day $30(p=0.030)$, the GuttaFlow Bioseal subgroup on day $7(p<0.05)$, the
GuttaFlow Bioseal subgroup on day $30(p=0.031)$, and the MTA Angelus subgroup on day $7(p<0.05)$.

A statistically significant relationships was also detected between the MTA Angelus subgroup on day 7 and the control subgroup on day $7(p<0.05)$, the control subgroup on day $30(p<0.05)$ and the GuttaFlow Bioseal subgroup on day $30(p<0.05)$. There was also a statistically significant relationship between the MTA Angelus subgroup on day 30 and the MTA Angelus subgroup on day 7 $(p<0.05)$, the control subgroup on day $30(p=0.031)$ and the GuttaFlow Bioseal subgroup on day $7(p<0.05)$.

Additionally, a significant relationship was detected between the GuttaFlow Bioseal subgroup on day 7 and the control subgroup on day $7(p<0.05)$, the control subgroup on day $30(p<0.05)$ and the GuttaFlow Bioseal subgroup on day $30(p<0.05)$.

There was a non-significant increase in the collagen fiber diameter among the subgroups with time.

\section{Discussion}

The biocompatibility of root-end filling cements is one of the most important requirements of the material, since it comes into direct contact with the vital periradicular tissues. In vivo subcutaneous implantation is considered one of the most reliable procedures to assess the biocompatibility of dental materials. ${ }^{21}$ The endodontic cement extruded from the polyethylene tube orifice creates a tissue-tube interface, which triggers inflammatory response similar to that found at the periapical area of an endodontically treated tooth. ${ }^{22}$ Inert polyethylene tubes were used for implantation due to their ability to hold the tested material in direct contact with the tissues. ${ }^{21}$ An additional empty tube was implanted as a control in an attempt to control variables, avoid selection bias, and neutralize any confounders that might affect the results. ${ }^{16}$

In this study, stromal inflammatory response (mononuclear cells), vascular changes, fibrous tissue formation, and the presence of MNGCs in the subcutaneous tissues of the rats were evaluated. In all subgroups, the results showed a moderate to severe stromal inflammatory response presented as the recruitment of inflammatory cells, numerous blood vessels and irregular collagen fibers with the presence of MNGCs. Following the initial moderate to severe 
reactions, all tissue reactions decreased over time. In addition, the structural reorganization of the capsules was demonstrated over time. This is a positive indicator of the material tolerability, as it is considered an immune reaction that produces foreign bodies recognized as harmless. ${ }^{23}$

Besides the recruitment of inflammatory cells, angiogenesis is essential for fibroblast proliferation and initial granulation tissue formation. ${ }^{24}$ The number of blood vessels decreased with time, which may be directly associated with the regression of the inflammatory reaction and the rearrangement of the connective tissue. On day 30, the control subgroup showed the least number of blood vessels, followed by the GuttaFlow Bioseal and MTA Angelus subgroups; the greatest values were associated with Zical.

Multinucleated giant cells could be observed, as demonstrated in Fig. 2A and 2C. These giant cells disappeared with time over the course of the study. These findings are consistent with the results of another in vivo study by Ghanaati et al. ${ }^{25}$ In their study, the number of MNGCs decreased with time as the degradation of the material progressed, suggesting that MNGCs were the main phagocytic cells associated with the degradation of the material. ${ }^{25}$ Additionally, Hernandez-Pando et al. proposed that MNGCs contributed to the initiation and maintenance of the inflammatory process, and might also be involved in the downregulation of inflammation and the induction of the fibrotic process via the production of proinflammatory and anti-inflammatory cytokines, depending on the inflammatory process phase. ${ }^{26}$ Notably, it is possible that the apoptotic cell death mechanism was involved in the elimination of MNGCs in the tissues. ${ }^{26}$

GuttaFlow Bioseal promoted connective tissue remodeling similar to that observed in the control subgroup, which indicates that the material was well tolerated by the tissues. It induced the formation of the collagenous capsule containing blood vessels and fibroblasts with mild inflammation 30 days after subcutaneous implantation. In previous studies, GuttaFlow cements (GuttaFlow and GuttaFlow 2) showed low cytotoxicity, ${ }^{27,28}$ which is an essential requirement for endodontic cements that come in contact with vital tissues. GuttaFlow Bioseal has been found to be slightly soluble when in contact with water due to the presence of soluble bioactive particles. This solubility is within the American Dental Association (ADA) specifications and has been suggested to provide the necessary ions needed for the remineralization of dentin. ${ }^{10}$ In an in vitro study on GuttaFlow Bioseal cultured on human periodontal ligament stem cells (hPLSCs), GuttaFlow showed the least cytotoxicity, maintained cell viability, and exhibited better cell migration, morphological characteristics and cytoskeletal organization patterns. In another in vitro study, GuttaFlow Bioseal was found to be the most biocompatible when cultured on mouse fibroblast cells as compared to GuttaFlow 2, AH Plus and MTA Fillapex. ${ }^{7}$

MTA Angelus showed the accentuated recruitment of inflammatory cells on day 7 . This elevated inflammatory reac- tion in the initial assessment period may be due to the high alkaline $\mathrm{pH}$ reached by the cement during setting, leading to the production and release of proinflammatory cytokines. ${ }^{29}$ Additionally, MTA has shown a cytotoxic effect on V79 fibroblasts and BALB/C 3T3 cells, which may be due to the presence of toxic components, such as salicylate and diluting resins. ${ }^{30}$ This is in accordance with the findings of this study, showing that the MTA Angelus subgroup demonstrated inflammatory cell infiltration on day 7 , which decreased until day 30, although it was still evident. ${ }^{31}$

Zical demonstrated the highest inflammatory infiltration throughout the study, which may be attributed to its constituents - zinc oxide ions and eugenol oil. These findings are consistent with an in vivo study showing an intense histopathologic reaction to a $\mathrm{ZnO} / \mathrm{E}$ sealer throughout the experimental duration, with profuse lymphoplasmacytic infiltrate and large quantities of macrophages. ${ }^{32}$ Similarly, $\mathrm{ZnO} / \mathrm{E}$ endodontic sealers caused a mild to moderate inflammatory reaction with a predominance of lymphocytes subcutaneously in rats, which declined into a mild reaction at the later period of the experiment. ${ }^{33}$ The setting reaction of this cement involves the hydrolysis of zinc oxide ions to zinc hydroxide, which chelates with eugenol oil in order to give a relatively soluble matrix of zinc oxide and eugenol with trapped unreacted eugenol. ${ }^{10} \mathrm{~A}$ study on the cytotoxicity of eugenol reported that it had a significant potential for periapical toxicity. Eugenol leaches out into the surrounding periapical tissues, contributing to the development of periapical inflammation, or even the persistence of a pre-existing periapical lesion. ${ }^{34}$ Eugenol may inhibit macrophage function by significantly affecting their adherence and potential for phagocytosis, which results in inflammatory reactions in the periapical tissues. ${ }^{35,36}$ On day 30, there was a significant reduction in the inflammatory response produced by Zical. This might be explained by the neutralization of the previously liberated eugenol, since Zical is a $\mathrm{ZnO} / \mathrm{E}$-based sealer. ${ }^{35,36}$

The control subgroup in both time periods showed inflammatory reactions, and since polyethylene is an inert material, they may have been triggered by trauma from the surgical procedure. ${ }^{37}$ Accordingly, the inflammatory reaction brought about by the experimental cements was due to both the surgical procedure and their components released into the surrounding tissues. This observation makes it evident that although the cements did show inflammatory response, they were still considered biocompatible if the level of inflammatory reponse was acceptable and restricted to short periods of time. ${ }^{38}$

\section{Conclusions}

Within the limitations of this study, Zical showed the greatest inflammatory reaction, while GuttaFlow Bioseal exhibited the least inflammatory reaction. Hence, it can be concluded that GuttaFlow Bioseal is biocompatible and comparable to MTA Angelus, making it a promising root canal sealer. It is 
recommended that other stains are used in future studies for enhanced detection of collagen fibers, such as MassonGoldner or picrosirius red staining.

\section{ORCID iDs}

Dina Rady (1) https://orcid.org/0000-0002-9672-6935

Mai Hisham Abdel Rahman (1) https://orcid.org/0000-0003-4934-6064 Sara El-Mallah (1) https://orcid.org/0000-0003-2050-5877

Mennatullah Mohammed Khalil (10 https://orcid.org/0000-0002-4944-7415

\section{References}

1. Mittal M, Chandra S, Chandra S. Comparative tissue toxicity evaluation of four endodontic sealers. J Endod. 1995;21(12):622-624. doi:10.1016/S0099-2399(06)81116-7

2. Torabinejad M, Ford TRP. Root end filling materials: A review. Endod Dent Traumatol. 1996;12(4):161-178. doi:10.1111/j.1600-9657.1996. tb00510.x

3. Bhagat $K$, Goel M, Bhagat N. Root-end filling materials and recent advances: A review. Indian J Appl Res. 2017;7(6):257-260. https://www. worldwidejournals.com/indian-journal-of-applied-research-(IJAR)/ recent_issues_pdf/2017/June/June_2017_1496324940__96.pdf. Accessed August 1, 2020.

4. Saxena P, Gupta SK, Newaskar V. Biocompatibility of root-end filling materials: Recent update. Restor Dent Endod. 2013;38(3):119-127. doi:10.5395/rde.2013.38.3.119

5. Priyanka SR. A literature review of root-end filling materials. IOSR-JDMS. 2013;9(4):PP20-PP25. doi:10.9790/0853-0942025

6. Scelza MZ, Coil J, Alves GG. Effect of time of extraction on the biocompatibility of endodontic sealers with primary human fibroblasts. Braz Oral Res. 2012;26(5):424-430. doi:10.1590/s1806-83242012000500008

7. Saygili G, Saygili S, Tuglu I, Capar ID. In vitro cytotoxicity of GuttaFlow bioseal, GuttaFlow 2, AH-Plus and MTA Fillapex. Iran Endod J. 2017;12(3):354-359. doi:10.22037/iej.v12i3.15415

8. Gandolfi MG, Siboni F, Prati C. Properties of a novel polysiloxaneguttapercha calcium silicate-bioglass-containing root canal sealer. Dent Mater. 2016;32(5):e113-e126. doi:10.1016/j.dental.2016.03.001

9. Tanomaru-Filho M, Torres FF, Chávez-Andrade GM, et al. Physicochemical properties and volumetric change of silicone/bioactive glass and calcium silicate-based endodontic sealers. J Endod. 2017;43(12):2097-2101. doi:10.1016/j.joen.2017.07.005

10. Khalil MM, Abdelrahman MH, El-Mallah S. Bond strength and solubility of a novel polydimethylsiloxane-gutta-percha calcium silicatecontaining root canal sealer. Dent Med Probl. 2019;56(2):161-165. doi:10.17219/dmp/105626

11. Oh MJ, Jeong YN, Bae IH, et al. Biocompatibility of experimental mixture of mineral trioxide aggregate and glass ionomer cement. J Korean Acad Conserv Dent. 2010;35(5):359-367. doi:10.5395/JKACD.2010.35.5.359

12. Bernabé PF, Holland R, Morandi R, et al. Comparative study of MTA and other materials in retrofilling of pulpless dogs' teeth. Braz Dent J. 2005;16(2):149-155. doi:10.1590/S0103-64402005000200012

13. Kaup M, Schäfer E, Dammaschke T. An in vitro study of different material properties of Biodentine compared to ProRoot MTA. Head Face Med. 2015;11:16. doi:10.1186/s13005-015-0074-9

14. Tyagi S, Mishra P, Tyagi P. Evolution of root canal sealers: An insight story. Eur J Gen Dent. 2013;2(3):199. doi:10.4103/2278-9626.115976

15. Abd El Rahman MH, Khalil MM, El Mallah S. Physical properties of an endodontic sealer containing calcium silicate. Egypt Dent $J$. 2020;66(3):1649-1655. doi:10.21608/EDJ.2020.26646.1087

16. Rady D, Mubarak R, Abdel Moneim RA. Healing capacity of bone marrow mesenchymal stem cells versus platelet-rich fibrin in tibial bone defects of albino rats: An in vivo study. F1000Res. 2018;7:1573. doi:10.12688/f1000research.15985.1

17. Omidi S, Javidi M, Zarei M, Mushakhian S, Jafarian A. Subcutaneous connective tissue reaction to a new nano zinc-oxide eugenol sealer in rat model. Iran Endod J. 2017;12(1):64-69. doi:10.22037/iej.2017.13

18. Schindelin J, Arganda-Carreras I, Frise E, et al. Fiji: An open-source platform for biological-image analysis. Nat Methods. 2012;9(7):676-682. doi:10.1038/nmeth.2019

19. Parirokh M, Mirsoltani B, Raoof $M$, Tabrizchi $H$, Haghdoost AA. Comparative study of subcutaneous tissue responses to a novel root-end filling material and white and grey mineral trioxide aggregate. Int Endod J. 2011;44(4):283-289. doi:10.1111/j.13652591.2010.01808.x
20. Chamberlain LJ, Yannas IV, Hsu HP, Spector M. Connective tissue response to tubular implants for peripheral nerve regeneration: The role of myofibroblasts. J Comp Neurol. 2000;417(4):415-430. doi:10.1002/(sici)1096-9861(20000221)417:4<415::aid-cne3>3.0.co;2-9

21. Gomes Moura CC, Cunha TC, Crema VO, Dechichi P, Gabrielli Biffi JC. A study on biocompatibility of three endodontic sealers: Intensity and duration of tissue irritation. Iran Endod J. 2014;9(2):137-143. PMID:24688584.

22. da Fonseca Roberti Garcia L, Franco Marques AA, de Moraes Rego Roselino L, de Carvalho Panzeri Pires-de-Souza F, Consani S. Biocompatibility evaluation of Epiphany/Resilon root canal filling system in subcutaneous tissue of rats. J Endod. 2010;36(1):110-114. doi:10.1016/j.joen.2009.09.012

23. Catanzaro Guimarães SA, Percinoto $C$. Effect of some endodontic materials on the influx of macrophages and multinucleated giant cell development in experimental granulomas. J Endod. 1984;10(3):101-104. doi:10.1016/s0099-2399(84)80224-1

24. Hankenson KD, Gagne K, Shaughnessy M. Extracellular signaling molecules to promote fracture healing and bone regeneration. Adv Drug Deliv Rev. 2015;94:3-12. doi:10.1016/j.addr.2015.09.008

25. Ghanaati $S$, Orth $C$, Barbeck $M$, et al. Histological and histomorphometrical analysis of a silica matrix embedded nanocrystalline hydroxyapatite bone substitute using the subcutaneous implantation model in Wistar rats. Biomed Mater. 2010;5(3):35005. doi:10.1088/1748-6041/5/3/035005

26. Hernandez-Pando R, Bornstein QL, Aguilar Leon D, Orozco EH, Madrigal VK, Martinez Cordero E. Inflammatory cytokine production by immunological and foreign body multinucleated giant cells. Immunology. 2000;100(3):352-358. doi:10.1046/ j.1365-2567.2000.00025.x

27. Zoufan K, Jiang J, Komabayashi T, Wang YH, Safavi KE, Zhu Q. Cytotoxicity evaluation of Gutta flow and endo sequence BC sealers. Oral Surg Oral Med Oral Pathol Oral Radiol Endod. 2011;112(5):657-661. doi:10.1016/j.tripleo.2011.03.050

28. Konjhodzic-Prcic A, Gorduysus O, Kucukkaya S, Atila B, Muftuoglu $\mathrm{S}$, Zeybek D. In vitro comparison of cytotoxicity of four root canal sealers on human gingival fibroblasts. Med Arch. 2015;69(1):24-27. doi:10.5455/medarh.2015.69.24-27

29. Yaltirik M, Ozbas $H$, Bilgic B, Issever $H$. Reactions of connective tissue to mineral trioxide aggregate and amalgam. J Endod. 2004:30(2):95-99. doi:10.1097/00004770-200402000-00008

30. Bin CV, Valera MC, Camargo SEA, et al. Cytotoxicity and genotoxicity of root canal sealers based on mineral trioxide aggregate. J Endod. 2012;38(4):495-500. doi:10.1016/j.joen.2011.11.003

31. Karabulut B, Dönmez N, Göret CC, Ataş C, Kuzu Ö. Reactions of subcutaneous connective tissue to mineral trioxide aggregate, Biodentine ${ }^{\circledR}$, and a newly developed BioACTIVE base/liner. Scanning. 2020;2020:6570159. doi:10.1155/2020/6570159

32. Scarparo RK, Grecca FS, Fachin EV. Analysis of tissue reactions to methacrylate resin-based, epoxy resin-based, and zinc oxideeugenol endodontic sealers. J Endod. 2009;35(2):229-232. doi:10.1016/j.joen.2008.10.025

33. Trichês KM, Júnior JS, Calixto JB, et al. Connective tissue reaction of rats to a new zinc-oxide-eugenol endodontic sealer. Microsc Res Tech. 2013;76(12):1292-1296. doi:10.1002/jemt.22299

34. Ho YC, Huang FM, Chang YC. Mechanisms of cytotoxicity of eugenol in human osteoblastic cells in vitro. Int Endod J. 2006;39(5):389-393. doi:10.1111/j.1365-2591.2006.01091.x

35. Omidi S, Javidi M, Zarei M, Mushakhian S, Jafarian A. Subcutaneous connective tissue reaction to a new nano zinc-oxide eugenol sealer in rat model. Iran Endod J. 2017:12(1):64-69. doi:10.22037/iej.2017.13

36. Khashaba RM, Moussa M. In vivo biocompatibility of four endodontic sealers: A comparative study. J Dent Oral Surg. 2016;1(1):4-12. doi:10.18689/mjdl-1000102

37. Viola NV, Guerreiro-Tanomaru JM, Ferreira da Silva G, Sasso-Cerri $\mathrm{E}$, Tanomaru-Filho M, Cerri PS. Biocompatibility of an experimental MTA sealer implanted in the rat subcutaneous: Quantitative and immunohistochemical evaluation. J Biomed Mater Res B Appl Biomater. 2012;100(7):1773-1781. doi:10.1002/jbm.b.32744

38. Yesilsoy C, Koren LZ, Morse DR, Kobayashi C. A comparative tissue toxicity evaluation of established and newer root canal sealers. Oral Surg Oral Med Oral Pathol. 1988;65(4):459-467. doi:10.1016/0030-4220(88)90361-1 